\author{
Krzysztof Jarzęcki \\ https://doi.org/10.26485/AAL/2021/67/11
}

\title{
SOME REMARKS ABOUT THE ROMAN IMPERIAL COINAGE FROM 117 TO 138 AD
}

The Roman Imperial Coinage, Volume II - Part 3: From AD 117 - 138 Hadrian by R. A. Abdy with a section of medallions by P. F. Mittag, general editors M. Amandry, A. Burnett, R. Bland, C. Howgego, series co-ordinator E. Howard, Spink, London 2019, 358 pp. +218 pl.

The Roman imperial coinage from 117-138, covering the issues of Emperor Hadrian, Sabina, Plotina, Aelius, and Antoninus Pius, has already been prepared in many ways. These include both widely known and cited works, such as Cohen (1859), RIC (1923), BMC (1966), as well as less known, although developed at a high level, an example of which is the work of P. L. Strack from 1933. ${ }^{1}$ The development of research on Roman imperial coinage, manifested by the discovery of previously unknown coins and an increase of knowledge about their production and circulation, forces the publication of this type of study. The increase in knowledge about Roman coins in the years 117138 has been huge in recent years and applied to virtually every aspect of them. This phenomenon has been compounded by the flow of information on the Internet. As a result, often it met the opinion that it is not difficult to find a coin that is not published in the RIC and the information, given that there are often outdated. The new volume of RIC, covering the coinage from Hadrian's time, was a much-needed and long-awaited work. Its preparation was undoubtedly difficult not only because of the enormity of the material but also the need to face the ,legend' of RIC - the high level of this series and the awareness that for the next several dozen years it will be a work that will be studied in detail and commented on. This task was undertaken by two researchers: Richard Abdy from

1 Strack P. L. 1933. Untersuchungen zur römischen Reichsprägung des zweites Jahrhunderts. Teil II, Die Reichsprägung zur Zeit des Hadrian, Stuttgart. Przykład cytowania w polskiej literaturze: Bodzek J. 2006. Dawne i nowe znaleziska monet rzymskich $\mathrm{w}$ archiwum i zbiorze Muzeum Narodowego w Krakowie. Część II [in:] Nowe znaleziska importów rzymskich z ziem Polski III, ed. A. Bursche, R. Ciołek, Warszawa, p. 210. the British Museum (coins) and Peter Franz Mittag from Universität $\mathrm{zu}$ Köln (medallions). They were supported by an editorial team of experienced and respected researchers: Michel Amandry (France) and Andrew Burnett, Roger Bland, Chris Howgego (Great Britain). The result of this work was a peer-reviewed book, published in London in 2019.

The book differs in many ways from the old RIC. To make it easier to use it was given "Notes on the use of the volume". In the "General Introduction" there is a description of the Roman coinage in a given period, among others "Weight standards and fineness", "Barbarian coins, plated coins, hybrids, mules, tooled coins", "Die studies", "Hoards and circulation". Much space was devoted to comments on the chronology (pp. 9-35) and the general characteristics of coin types (pp. 3659). Information is also provided on medallions and medallion coins (p. 60-67) with a simple but very legible diagram of stamp connections, which could be a model for presenting this type of data. The work also includes an Appendix, by Quanyu Wang, Compositional analysis of silver and aes coins of Hadrian minted at Rome and in the provinces (p. 68-74). The volume of the catalog part is very impressive, at first glance much larger than the old RIC. The last directory number is 3204 . Each entry contains a few references. This is very often the aforementioned work by Strack which describes many coins not recorded in the old RIC and BMC. By the way, we will find there, as in the reviewed work, all types of denarii from the hoard from Drzewicz, which were considered to have no analogies in the literature. ${ }^{2}$ It is worth emphasizing

2 Krzyżanowska A. 1976. Skarb denarów rzymskich z Drzewicza, Zakład Narodowy im. Ossolińskich. 
the references to the numismatic collection of the Hermitage in Saint Petersburg (no. 718, 1523, 1782 , etc.) - a great one, absent from the old RIC. The author also often refers to information about coins from auction houses and, which is a sign of the times and what the reviewed work has greatly benefited from, coins from private collections. An example is the collection of Evgeniy (in RIC 'Zhenya') Marinkevich from Ukraine, which includes an interesting hybrid denarius with the obverse of Aelius and the reverse of Hadrian (no. 2637). The Polish accent in the reviewed book is the reference to Gabriela Sukiennik's work from 1991 on coins from the Ossolineum. For each type of coins and medallions, the frequency of their occurrence is given on a six-point scale. This is a big advantage. The reviewed work differs from the old RIC, among other things, in the selection of material. In addition to imperial coins includes medallions $^{3}$ (as Cohen's work), but omits anonymous quadrantes produced from Domitian to Antoninus Pius, which will be published in the next volume, and cistophori. These changes are well-founded, and the book has gained thanks to them. Each work section, apart from the description of the obverse and reverse, contains information about the die-axis. This is a good decision, probably inspired by BMC. As shown, the die-axis is related to the chronology of coins, which can be of great importance, for example, in the case of Sabina coins. The work contains the Introduction, legends and types indexes as well index of concordance RIC II first edition to second, including notes to old RIC. At the end of the book there are 218 plates with illustrations. Their number is particularly impressive if we take into account that in relation to the RIC from 1923 , the increase in illustrations is $2700 \%$. The book overall makes a very good impression, but unfortunately, it also has errors and imperfections.

There were many orthographic mistakes in the work, e.g. 'setserci' (p. XVI), 'moenta' (p. XVII) etc. Especially often they appear in words in Italian. In the catalog part, the number 106 is repeated twice (p. 83). The method of numbering the coins leaves much to be desired. There are many numbers missing from the work: 180189 (p. 89), 284-292 (p. 97), 488-496 (p. 109), 690-707 (p. 121-122), 761-771 (p. 127), 836-844 (p. 132), 900-910 (p. 137), 1000-1008 (p. 143144), 1388-1396 (p. 167-168), 1449 (p. 172), 14651474 (p. 173), 1970-1976 (p. 207), 2059-2062

3 Cf. Mittag F. P. 2012. Römische Medaillons: Cesar bis Hadrian, Stuttgart. (p. 212), 2183-2197 (p. 219-220), 2301-2311 (p. 227), 2439-2446 (p. 236-237), 2465-2474 (p. 239), 2510 (p. 243), 2612-2620 (p. 250-251), 2777-2785 (p. 263), 2974-2981 (p. 280), 30163024 (p. 283), 3119-3126 (p. 289), 3185-3192 (p. 292). In total, over 200 items are missing. As the authors write, "One sequence of numbering is used throughout this volume but with small gaps of unused numbers between sections which has the construction of the catalogue and allows room for expansion in future editions" (p. xxiii). It is a fatal decision that creates chaos. The more so that the number of vacancies is different, as if the authors knew in advance how much space is needed "for expansion in future editions" and according to what rules they will be edited to reflect the future state of knowledge. Let us hope that the authors of the next volumes of RIC "in active preparation" (p. V) will not decide to take a similar step. A sample of what chaos it introduces can be seen in the reviewed work, where in the "General Editor's Foreword" we read that the work includes "over 3000 entries", and this is not true. The disadvantage of the reviewed work is the lack of references to some important publications from the perspective of the research undertaken. An example of what is absent from the RIC is a large hoard of bronze coins from Biassono (Italy, Lombardy). ${ }^{4}$ And it should be taken into account for many reasons. As is known, among other things, from $\mathrm{N}$. Elkins' research on Nerva coins, ${ }^{5}$ coin hoards differ in composition (coin types) depending on the region in which they are found. It would be very valuable to include this type of find (referred to in Italian literature by the term 'ripostiglio' indicating its nature) reflecting the money circulation in the heart of the Roman Empire. It is a pity that the author does not refer to him in the cata$\log$ as well as to the Garonne hoard, because it is also a find very well developed and displayed in the museum, and thus easy to verify by other researchers. Another find that has no appeal at work, which has had a negative effect on the whole, is the hoards of denarii from Nietulisko Małe in Poland. There is a well-known and often-cited book in English by Kunka Mitkowa-Szubert devoted to them. ${ }^{6}$ The hoard includes a denarius not listed in

4 Arslan E. A. 1995. Il ripostiglio di Biassono (Milano) 1975 (monete romane imperiali), parte I (Octavianus Augustus - Faustina II), Milano.

5 Elkins N. T. 2017. The Image of Political Power in the Reign of Nerva, AD 96-98, Oxford, p. 98.

6 Mitkowa-Szubert K., The Nietulisko Małe Hoards of Roman Denarii, Warszawa. 
the reviewed book: with the word HANDRIANVS in the legend ${ }^{7}$ and the second with the legend SALVS AVGVSTI COS III on the reverse. ${ }^{8}$ In addition to errors, the work also contains discussion fragments. It is a pity that the authors did not use their knowledge to note the fact that some information is controversial and did not attempt to solve the problems that had existed for years. One is the problem of whether certain bronze coins should be classified as dupondii or asses. As the work shows, the denominator of the denomination is the color of the metal, and the reason for the lack of clear definition is the patina on the coin ('although the user in antiquity would have had no problem so long as metal colour could be seen' p. 2). In the age of space flight, such a statement sounds like a joke. A researcher dealing with the great collection of the British Museum must have seen many coins without patina that contradict this view. The metal criterion seems questionable if we consider that coins had to be recognized in antiquity in a way that was flawless, easy and quick. Weight could not be the criterion either, because in this respect dupondii were heavier than asses by an average of several percent. It is possible that the only indication that the coin is a dupondius, after the reform of Nero, is the presence of a corona radiata. ${ }^{9}$ One consequence of adopting such a hypothesis would be that empress Sabina did not have 'her' dupondi. At the same time, the problem of determining the denomination of a coin held in the hand, even in perfect darkness, would practically disappear. Another issue that is debatable is the chronology of Sabina's hairstyles The work shows that Sabina was portrayed interchangeably with different hairstyles. Such conclusions may be prompted by the analysis of its representations on coins minted by at least 79 different centers in the eastern provinces of the Roman Empire. A striking example are the Alexandrian coins from the year 15 (130/131 AD), where Sabina is depicted on the obverse and the reverse with different hairstyles (RPC 5772). ${ }^{10}$ The question remains whether such cases can be considered as a direct reflection of the customs prevailing in imperial coinage. Taking into account the specificity of provincial coinage,

7 Ibid. no. 227.

8 Ibid. no. 305.

9 Jarzęcki K. 2018. Mennica rzymska za Didiusza Juliana, Warszawski Pamiętnik Numizmatyczny, 6, p. 30.

10 Cf. Jarzęcki K. 2015. Monety z przedstawieniem cesarzowej Sabiny we wschodnich prowincjach Cesarstwa Rzymskiego, Warszawski Pamiętnik Numizmatyczny, 4, p. 20. it seems highly doubtful. At the same time, it is known that Faustina II, Lucilla, Crispina, ${ }^{11}$ Julia Domna, Plautilla etc. never reverted to old hairstyles. It is worth looking at Sabina's coins in this key as well, because it is very possible that it was the same in her case. It is a pity that this possibility has not been explored. There is also a feeling of dissatisfaction with the information about one of Sabina's posthumous denarii with "unbraided hair piled up" (RIC 2608, old RIC 422c). There has long been a hypothesis that this coin was minted after Hadrian's death. ${ }^{12}$ It was presented, among other things, in the above-mentioned book about denarii from Nietulisko ${ }^{13}$ and repeatedly in the descriptions of coins put up at auctions. ${ }^{14}$ It is a pity that it was not recorded in the reviewed book.

Despite the errors and shortcomings, the overall assessment of this work is positive. Its weakest point is the part devoted to Sabina's coins, the best part is devoted to medallions. It is worth using it, because after all this is currently the best work dedicated to the imperial coins and medallions from the time of Hadrian

Krzysztof Jarzęcki

ORCID 0000-0002-4137-9729

The Leon Wyczótkowski District Museum in Bydgoszcz

krzysztof.jarzecki@gmail.com

11 Eg. Szaivert W. 1989. Die Münzprägung der Kaiser Marcus Aurelius, Lucius Verus und Commodus (161-192), Wien.

12 Jarzęcki K., 2019. Struktura wagowa denarów rzymskich z lat 138-161, Acta Archaeologica Lodziensia, 65, p. 162.

13 Mitkowa-Szubert K., The Nietulisko..., p. 95.

14 Jean Elsen \& ses Fils S.A., auction 95, lot 393, 15.03.2008, 447756; Stack's Bowers Galleries, January 2013 N.Y.I.N.C., lot 5387, 08.01.2013, 1484899; Hess Divo AG, auction 333, 30.11.2017, lot 191, 4575056; Roma Numismatics Limited, E-Sale 54, lot 729, 28.02.2019, 5704956, etc. 